\title{
The correlation between educator-turnover and the promotion of efficient management in public schools in Soweto, South Africa
}

\author{
Louise Van Scheers* and Jan Wiid \\ School of Business Management, University of South Africa, South Africa. \\ Accepted 16 December, 2010
}

\begin{abstract}
Over three decades, the conditions under which teachers work have always been short of lending themselves to high quality education. Most of the present teachers in the townships do not have high quality education because the government at that time allocated minimal funds for the education of Black people. When the democratically elected government came to power in 1994 it was determined to make education offered to its citizens, equal. A new curriculum was introduced that will teach learners to apply their minds in a way that will equip them with life-skills. More funds were allocated to the previously disadvantaged schools. Then there were reports that the minister is concerned about the number of teachers who are leaving the profession and the small number of young people who are attracted to the profession; and that is what triggered this research. The research analyse the correlation between educator-turnover and the promotion of efficient management in public schools in Soweto, South Africa. From the survey conducted in the schools that participated in the research, there was evidence that the majority of teachers chose the profession because they loved it and because they felt they were making a contribution to the society. The results of the research also revealed the average number of teachers who resign per year is very low but many teachers left the profession when the government gave teachers options to take 'packages' and leave the profession forever. The concluded that the reason so many teachers are unhappy, is poor management. The researcher recommends that the South Africa government organise training programmes for managers of schools. There should be continuous and effective development of school managers and that the present programmes should be investigated as to their relevance and effectiveness.
\end{abstract}

Key words: Promotion of efficient management skills, job satisfaction, educator-turnover, public schools in Soweto, management, education.

\section{INTRODUCTION}

In the past years there has been a growing concern that fewer young people are interested in considering teaching as a career and also that young educators are leaving the profession. One reason could be that South Africa is fast becoming a capitalistic country, with most of the youth's role models wearing designer clothing, driving expensive cars and living in expensive houses. The consequences of this are the learners in Soweto cannot aspire to be teachers because the teachers they see do not wear the designer clothes they like and the state of

${ }^{*}$ Corresponding author. E-mail: dr.louisevsc@gmail.com or vscheml@unisa.ac.za the environment in which they work is not attractive, to say the least. The teachers who are already in the field also feel they are missing out with all the opportunities available to their peers (in other careers) i.e. of improving their financial and social status. High turnover rate of educators in schools has mostly been seen as having negative implications on the successful running of schools.

\section{Problem statement}

The problem that is facing the Soweto schools is the shortage of qualified educators and those who are 
committed to the profession, that is, those who chose it because they love it and understand the importance of their roles. It is not enough to have appropriately qualified educators, they should also have experience. Fortunately the current minister of education is aware of this fact. According to Pretorius (2004) the minister, Ms. Pandor said educators' salaries need to be improved, especially those of more experienced teachers. When educator turnover is too high then schools will be manned by educators who are new in the profession and are still learning the robes, doing trial and error. That is not good enough if the department of education hopes to turnaround the standard of education in schools.

The Sub-problems of the study are:

Career advancement: Educators have been complaining about the salaries that hinge on promotions. Consequently if one's particular school has no promotional posts, one has to be content with what they have or move elsewhere.

Absence of recognition: There is no acceptable way of recognising and rewarding the good work done by educators. This is demotivating and lowers the morale of educators. The result is they exit the system.

Working conditions: Another problem facing the department of education is to improve the working conditions of educators. They have been complaining about heavy workloads, poorly resourced schools, lack of safety in schools, overcrowded classrooms poor discipline, and increased responsibility to handle learners with special problems.

Lack of managerial skills: The promotion of teachers to managerial positions, that is, principal's posts or subjectspecialist's post is not efficient because some are promoted because of experience in the field and others because they have been producing good results. A good teacher may not automatically be a good manager.

\section{Objectives}

The research aims to analyse the correlation between educator-turnover and the promotion of efficient management in public schools in Soweto, South Africa.

The objectives of the research are to:

i) Analyse relationship between educator-turnover and the promotion of efficient management

ii) Investigate perceptions of educators about the turnover rate

The next step the researcher will take is to conduct a literature review. According to Borg and Gall (Saunders et al., 2007) one of the purposes of literature review is for the researcher to discover explicit recommendations for further research that will enable them to focus their own research question and sub problems. To attain the objective of this article, the following hypotheses were drawn:

$\mathbf{H}_{1}$ : There is a correlation between educator-turnover and the promotion of efficient management in public schools in Soweto, South Africa.

$\mathbf{H}_{2}$ : There is a correlation between educators' perceptions and the turnover rate in public schools in Soweto, South Africa.

\section{Literature review}

Most of the schools in the townships are still in the process of rebuilding the culture of serious teaching and learning which had deteriorated after the 1976 student uprising. At the moment there are two 'types' of public schools, the township schools (including Soweto schools) and the schools in previously white suburbs (used to be Model C schools). The political history of discrimination and unequal allocation of educational funds have resulted in township schools offering lower quality education than the ones in previously white areas, e.g. shortage of resources.

\section{Background to the Soweto schools}

Secondary research (Neuman, 2000; Sono, 1999; Zille, 2004) observed that in Soweto schools progress is slower than in others however. According to Zille (2004) possible reasons for the slow progress could be huge administration loads for educators, inefficient and unsupportive department of education, absence of mechanisms to hold educators and officials accountable for students' results, weak educators, and low levels of parental involvement and poor alignment of investments with the desired education outcomes.

It seems from long ago teachers have had unsatisfactory working conditions and remuneration, especially the black teachers. Sono (1999) states "the system left a residue of disenchantment and resentment among African teachers, especially concerning the provision of education facilities and the remuneration of teachers, which was paltry". In 1931 a teacher who was a member of an organisation of teachers wrote that a Black teacher was not regarded as a teacher as such because she did not teach in a public building, was not entitled to pension privileges, had no security of tenure and that black education was financially strangled (Sono, 1999).

The 1990s period marked the beginning of ending many 
years of inequalities in education as the new democratic government took over. About this period Grobler (1999) states, "The fact that South Africans have experienced different educational histories is therefore a significant factor in the transition to a single, national non-racial system. It is now the joint responsibility of all South Africans who have a stake in the duration and the training systems to build a just, equitable and high quality system for all the citizens, with a common culture of disciplined commitment to learning and teaching". One of the biggest changes of this period was the adoption of the Constitution in 1996, which contained the Bill of Rights. According to Mda et al. (2000), this bill gave people a right, amongst others, to use their money to establish independent schools that do not practise racial discrimination as long as they are registered with the state and standards are maintained in such a way that they are not inferior to those of the public schools. The South African Schools Act (SASA) 84 of 1996 made a provision for admission polices that are non discriminatory.

The consequences of this for Soweto and other township schools in general was, those parents who could afford enrolled their children in previously "white" suburbs. Now these "white" schools at the time did not admit any learner who came knocking at their door. They gave all applicants to their schools an aptitude test. In other words they only admitted high achievers to their schools. Therefore the schools in SOWETO will be left with less high achieving learners and the teachers there will have to deal with more learners who had learning difficulties. In addition the township schools were left with a community of parents who come from poor economic, social and educational background. All these factors contributed to the stress that township educators face due to parents who are not skilled to run School Governing Bodies, parents who could not help their children with homework and cannot afford to buy additional learning aids needed.

It is unproductive for a business to waste energy and other resources recruiting and training educator if it cannot retain it. Cheatle (2001) states that "it is analogous to 'filling the bath with the plug left out'". Educator turnover is costly and disruptive to the organisation's continuity; it would be wise for an organisation to increase employees' job satisfaction. One way of analysing the reasons for the high turnover in public schools is to use the Service Profit Chain. "There are direct and strong relationships between profit; growth; customer loyalty; customer satisfaction; the value of goods and services delivered to customers; and employee capability, satisfaction, loyalty and productivity" (Heskett et al., 1997). This means when employees are satisfied with the jobs they are doing they become loyal to the organisation, the service quality for the customer (learners/parents) will increase, that will lead to customer satisfaction and customer loyalty. The end result in this case will be long-term high quality matric results and long-term loyalty of families bringing generation by generation of children to the school.

The first step therefore, is to look at what makes employees dissatisfied and therefore disloyal. Studies were done at Mariott Corporation on the importance of employee loyalty and the findings were that $10 \%$ reduction in employee turnover would raise turnover by $\$ 50 \mathrm{~m}$ to $\$ 150 \mathrm{~m}$ (Baron and Harris, 1995). In the case of schools therefore, the number of learners who get matric exemption will increase if good educators can be retained. The following are perceived reasons for dissatisfaction.

\section{Lack of appropriate incentives}

It has been established that when employees perceive that their employers are not treating them equitably, tension occurs and causes labour turnover, (Carell et al., 1998). For example there have been reports that some teachers were not paid on time and that others have been on temporary posts for more than ten years, (Mannering, 2004). However, there are other advantages to offering the highest rewards and one is that an organisation can attract more applicants for a post from whom it can choose the best, Swanepoel et al. (1998).

\section{Work environment}

The environment can contribute to the reduction of educator turnover because if you like where you work, that is, pleasant environment, there are people to support you, tools that are needed are there, etc, then there will be no reason for you to go anywhere. According to Huysamen (1999) the work environment consists of the technical environment (tools, technological infrastructure and other physical elements); human environment (peers, others with whom the employee relate, communication methods, leadership and management styles) and the organisational environment (organisational structure, the systems, procedures, practises, values and philosophies).

\section{Lack of management skills in the promotion of efficient management}

There are many officials who were appointed in senior positions, not because of their expertise or experience but to ensure all races are represented in management or as compensation for their contribution to the struggle, (Jansen, 2004). Even though this may have been necessary, appropriate training should have been offered so that when educators asked questions about the new 
policies and the new curriculum, they would get an acceptable explanation. They should not find themselves frustrated by lack of proper guidance. Managing a school or managing a number of schools is a different kind of work than teaching learners. It is therefore, essential for leaders in education to undergo both academic and professional training in educational management. Teacher training colleges and Universities should train teachers to teach but also train potential school leaders for the demands of higher positions, (Mampuru and Spoelstra, 1994).

\section{METHODOLOGY}

The research investigates the correlation between job satisfaction and educator-turnover in selected public schools in Soweto, South Africa. The researcher interviewed educators who are working in Soweto public high to find out their perceptions on educator turnover. According to Cooper and Schindler (1998) "Qualitative refers to the meaning, the definition or analogy or model or metaphor characterising something, while quantitative assumes the meaning and refers to the measure of it". The researcher intend using both data because qualitative data, for example, will be the perceptions of educators about the turnover of educators and quantitative data (statistics) will either support them or go against them. This will give the researcher the benefits of both data and the weaknesses of one will be balanced by the strengths of the other. Babbie (2001) states "A complete understanding of a topic often requires both techniques".

Stratified random sampling was used. According to Babbie (2001) this type of sampling makes sure the researcher selects appropriate numbers of elements from homogenous subsets of the population. For example Soweto schools fall under three districts and each school has young, inexperienced educators and older experienced educators. Samples were drawn from each district (suburbs), proportionally. Each sample is representative of both experienced and inexperienced educators, males and females. There are 68 high schools in Soweto, which have an average of 25 educators. The researcher interviewed educators from 15 public schools. Ten educators per school were interviewed and therefore the sample consisted of 150 educators.

\section{Measures}

The main construct of this study (location) was measured through the use of Likert-type scales as opposed to the demographic variables, like respondent income and age, whose questions delivered only nominal data. The basic scale design therefore consisted of a Likert-type scale with five scale points (with labels ranging from strongly agree to strongly disagree) and 11 scale items. This scale was found to be highly reliable with a Cronbach's alpha of 0.7 . The constructs measuring cherry picking behaviour as price searching across time and price searching across stores were measured using similar scales with five scale items. These two scales were also found to be reliable. No items on any of these scales were reverse scored.

\section{Inferential statistics}

In this study the researcher want not only to describe the sample data such as means, standard deviation and proportions but they wish to make inferences about the population based on what was observed in the sample. Inferential statistics allow researcher to make inferences concerning the true differences in the population (Tustin et al., 2005).

The following null and alternative hypotheses can be formulated:

$\mathrm{H}_{01}: \mu 1 \neq \mu 2$

$\mathrm{H}_{\mathrm{A} 1}: \mu 1=\mu 2$

\section{RESULTS}

\section{Descriptive statistics}

The study established that there are fewer young people joining the teaching profession because only $3 \%$ of the respondents were between the ages $20-30,38 \%$ of the representatives were between the ages $31-39,43 \%$ of the representatives were between the ages 40 to 49 and $16 \%$ were over $50 \%$. It is highly recommended that the DoE embark on a recruitment drive to attract young people to the profession; however an efficient and effective career guidance programme should be introduced in schools so that the right people for the job join the profession.

\section{Reasons teachers chose the profession}

Figure 1 indicates that the majority of teachers chose the profession because they loved it (37\%) and many thought it gave them an opportunity to make a contribution to society $(28 \%)$. However, there were quite a few teachers who said they chose the profession because it was the least costly way of getting a profession that is, $16 \%$.

\section{Salary}

Table 1 show that the majority (94\%) of the respondents stated they regret choosing this particular profession because their salaries are far too little as compared to their counterparts in the private sector. It is recommended therefore that the hiring of teachers should be well planned. As stated earlier it should begin with a career guidance programme so that people who take up teaching know exactly what they are getting into, including remuneration.

\section{Working conditions}

86 percent of the respondents felt the environment in which they work does not contribute to job satisfaction. The learning and teaching resources are never enough. Some school buildings are not conducive to proper learning and teaching. They also mentioned unfair distribution of workload. The drug trafficking problem was 


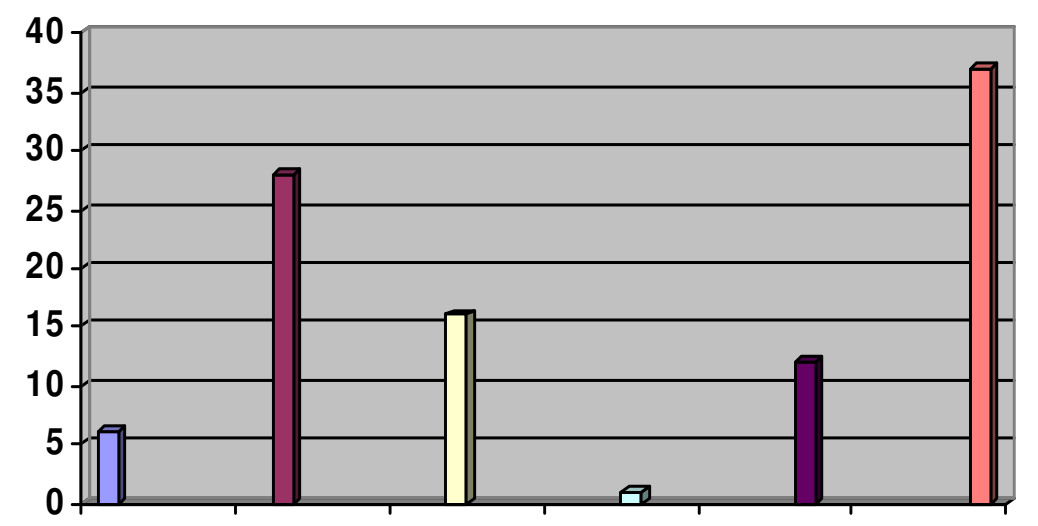

\begin{tabular}{|l|}
\hline Calling \\
$\square$ Contribution \\
$\square$ Low cost of training \\
$\square$ Noble profession \\
$\square$ Employability \\
$\square$ Love \\
\hline
\end{tabular}

Figure 1. Reasons teachers chose the profession.

Table 1. Factors affecting teachers' satisfaction with their job.

\begin{tabular}{lc}
\hline Factors & Percentage \\
\hline Salary & 94 \\
Working conditions & 86 \\
Lack of Management skills & 79 \\
Incentives & 89 \\
\hline
\end{tabular}

also a problem which worried about their safety when teaching learners who are smoking. It is recommended that it should be the duty of the school management to ensure that the working conditions of teachers are improved.

\section{Incentives}

$89 \%$ of the respondents indicated that there were no incentives to encourage them to continue working hard in their difficult jobs. The DoE does organise awards functions but these are usually national. It is recommended that school managers should have their own awards ceremonies for teachers and managers should not wait for end of the to recognise teacher achievements, but should begin with a pat on the back, a word of thanks at a educator meeting or assembly go a long way towards recognising one's good work.

\section{Lack of management skills}

Table 1 also indicates that 79 percent of the respondents stated they were unhappy with the management they have in schools. Management is responsible for acquiring and managing the resources for the school, for liaising with the parents and police in an effort to curb the drug problem. The Governing Bodies, principals and Heads of Departments in the school have to be trained on how to manage schools.

\section{The relationship between educator turn-over and the promotion of efficient management in public schools in Soweto, South Africa}

Table 1 also indicates that the majority of the respondents stated they were unhappy with the management they have in schools. The fact they are complaining about working conditions and lack of incentives indicates poor management of resources including people management. It is therefore, recommended that the DoE evaluates the management training programmes they use as to whether they are relevant and effective. It is no use for the government to pour lots of money in training, if it not improving the management of schools.

To achieve the objectives of the study, to determine whether there is a correlation between educator-turnover and the promotion of efficient management. The following hypotheses were formulated:

$$
\mathrm{H}_{01}: \mu 1 \neq \mu 2
$$$$
\mathrm{H}_{\mathrm{A} 1}: \mu 1=\mu 2
$$

Table 2 shows that the Pearson correlation indicates a 
Table 2. The Pearson correlation.

\begin{tabular}{llcc}
\hline & & Educator turn-over & $\begin{array}{c}\text { Total: Job satisfaction and } \\
\text { educator-turnover }\end{array}$ \\
\hline Educator turn over & Pearson correlation & 1 & 0.063 \\
& Sig. (2-tailed) &. & 0.448 \\
Total: Job satisfaction & $\mathrm{N}$ & 157 & 156 \\
and educator-turnover & Pearson correlation & 0.063 & 1 \\
& Sig. (2-tailed) & 0.448 &. \\
& $\mathrm{~N}$ & 157 & 156 \\
\hline
\end{tabular}

Table 3. The Pearson correlation.

\begin{tabular}{llcc}
\hline & & $\begin{array}{c}\text { Educators' } \\
\text { perceptions }\end{array}$ & $\begin{array}{c}\text { Total: Educators' perceptions and } \\
\text { turnover rate }\end{array}$ \\
\hline Educators' perceptions & Pearson correlation & 1 & 0.062 \\
& Sig. (2-tailed) & 157 & 0.446 \\
& $\mathrm{~N}$ & 0.062 & 157 \\
Total: Educators' perceptions & Pearson correlation & 0.446 & 1 \\
and turnover rate & Sig. (2-tailed) & 157 & 157 \\
& $\mathrm{~N}$ & & \\
\hline
\end{tabular}

perfect correlation of 1 at a significant level of 0.052 tailed. When conducting the z-test, $\mathrm{H}_{01}$ was rejected thus accepting $\mathrm{H}_{\mathrm{A} 1}$. Therefore, by accepting $\mathrm{H}_{\mathrm{A} 1}$, one may conclude that there is a significant correlation between educator-turnover and the promotion of efficient management.

The second objective of the study, there is a correlation between educators' perceptions and the turnover rate in public schools in Soweto, South Africa. The following hypotheses were formulated:

$\mathrm{H}_{02}: \mu 1 \neq \mu 2$

$\mathrm{H}_{\mathrm{A} 2}: \mu 1=\mu 2$

Table 3 shows that the Pearson correlation indicates a perfect correlation of 1 at a significant level of 0.052 tailed. When conducting the z-test, $\mathrm{H}_{02}$ was rejected thus accepting $\mathrm{H}_{\mathrm{A} 2}$. Therefore, by accepting $\mathrm{H}_{\mathrm{A} 2}$, one may conclude that there is a significant correlation between educators' perceptions.

\section{RECOMMENDATIONS}

\section{Remuneration}

The researcher would like to suggest that the problem of remuneration is closely related to hiring the right people for the job. This does not mean teachers need not be paid well, it just means the researcher thinks people who want high salaries will always be attracted by dangling carrots; besides the government cannot afford high salaries. The Department of Education should continue its present efforts of improving the salaries of teachers however, because it will show that teachers' services are appreciated. The recruitment should begin with the Department of Education developing a well planned programme of career guidance which will equip learners with a thorough knowledge of what type of person is needed for different careers.

\section{Work conditions}

The researcher would like to suggest that this is the school management's responsibility. The managers are vital in creating a pleasant and a productive workplace. The members of the SGBs and the SMTs should be well trained in order for them to know what their duties are and how to perform them well. They have an enormous task of supporting the school personnel in the performance of their professional duties. This includes correcting all the things teachers are complaining about e.g. safety, discipline, workloads, habitable classrooms, teaching and learning resources, etc.

Training should include budgeting, accounting and record keeping, reporting, law pertaining to schools, human relations management, etc. A well-managed 
school finds it easier to attract sponsors from the private sector so as to augment the funds and improve the functioning of the school.

\section{The role of management}

The school management should give deserving teachers more responsibilities over and above the teaching of their classes. An example of these responsibilities would be to appoint a teacher responsible for different sports, parental involvement, building maintenance, liaising with teacher training institutions, school image, and welfare of teachers. Teachers would not be paid for these responsibilities but it would make them feel good about themselves. Managers should be able to recognise the talents teachers have and utilise them. This will not only make teachers' jobs exciting and want to stay in their jobs but will also make those who do not like teaching to be 'marketable' in the labour market and leave. This will pave way for schools to recruit the right people for the job.

The researcher recommends that awards functions should not only be national but also organised for provincial, district, local and individual schools. The reason is many hard-working teachers may be overlooked. The researcher recommends that the school management also be trained on change management so that teachers embrace change. The researcher also recommends that training should include communication skills. Some of the information that the Department of Education sends to schools does not reach the teachers or reaches them late. Schools require good communication channels to avoid the breakdown in communication. Again there should be evidence that training has taken place.

\section{Managing turnover}

Schools should have a data bank where important information can be stored and be retrieved when needed, for example, a record of employees who resign, the reason for their resignation, some particular effective method of teaching a lesson (so that when a teacher leaves some of his or her knowledge is left behind). The researcher had difficulty finding data on turnover from schools. All the schools have computers but the researcher feels they are being under utilised. Therefore training in this regard will also be valuable to schools. schools is in alignment with the desired outcome. Soweto has gone down in history as the place where a revolution of education in 1976 started. It would be great if it could be the first township in which its residents are not forced by the poor quality of education offered in the township, to send their children to the schools in the previously 'white suburbs'. The research established that there is a correlation between educator-turnover and the promotion of efficient management. Effective managers will be able to identify all those factors that contribute to improving the quality of education for example, working conditions of teachers, and use the funds available accordingly.

\section{REFERENCES}

Babbie E (2001). The practice of Social Research, $9^{\text {th }}$ Edition, Belmont: Wadsworth.

Baron S, Harris K (1995). Service Marketing: Text \& Cases, London: Macmillan Press Ltd.

Carell MR, Grobler PA, Elbert NF, Marx M, Hatfield RD, Van der Schyf $S$ (1998). Human Resource Management: Prentice Hall South Africa (PTY) LTD.

Cheatle K (2001). Mastering Human Resource Management, New York: Palgrave.

Cooper DR, Schindler PS (1998). Business Research Methods, New York: McGraw-Hill Companies, Inc.

Grobler BR (1999). Management Of The School In Context: A guide to educators and managers in education, Lynwood Ridge: Amabhuku Publications (Pty) Ltd.

Heskett JL, Sasser JRWE, Schlesinger LA (1997). The Service Profit Chain: How Leading Companies Link Profit and Growth to Loyalty, Satisfaction and Value, New York: Free Press.

Huysamen D (1999). Rehumanised Productivity Improvement, Randburg: Knowledge Resources (Pty) Ltd.

Jansen J (2004). "Open letter to the education minister", Celebrating 10 years of democracy-supplement, City Press, April 25, p.16.

Mampuru C, Spoelstra M (1994). Negotiation Skills in Education Management, Kenwyn: Juta \& Co. Ltd.

Mannering $L$ (2004). "Teachers fight for their pay", Saturday Star, May 15.

Mda T, Mothata S (Editors) (2000). Critical Issues in South African Education - After 1994, Kenwyn: Juta and Company.

Neuman WL (2000). Social Research Methods: Qualitative and Quantitative Approaches, Fourth Edition, Boston: Allyn and Bacon.

Pretorius C (2004). "Pandor whips education into shape", This Day, July 29, p.4.

Saunders M, Lewis P, Thornhill A (2007). Research methods for business research, Second Edition, London: Pitman Publishing.

Sono T (1999). African Teachers' Struggle for Educational Justice in S.A.: 1906-1996 TUATA at the centre of the battle, Pretoria: J.L. van Schaik Publishers.

Swanepoel BJ, Erasmus BJ, Van Wyk MW, Schenk HW (1998). Human Resources Management: Theory \& Practice, Kenwyn: Juta \& Co. Ltd.

Tustin DH, Ligthelm AA, Martins JH, Van Wyk H de J (2005). Research Method in practice. Pretoria: Unisa Press.

Zille H (2004). "Let's pay teachers what they're worth", The Star, July 26, p.8.

\section{Conclusion}

The provincial government allocates a lot of funds to the schools in the previously disadvantaged areas. The question is, however, whether the investment in these 